\title{
3.B Economic Actors in the Arsakid Empire
}

\section{Introduction}

This chapter follows from the previous and concentrates on a particular range of economic actors that were involved in the financial administration of the Arsakid Empire. The Arsakid tributary system relied on a differentiated, hierarchical structure of central and regional officials cooperating with private entrepreneurs to collect, deposit, and manage tax revenue. Unfortunately, the scant and patchy evidence does not allow us to reconstruct a full picture across all regions under Arsakid influence. ${ }^{1}$ Instead, we must piece together a mosaic of preexisting Achaemenid and Seleukid practices, which the Arsakids do not seem to have changed radically, supplemented by evidence for the financial administration of cities and Babylonian temple administration. ${ }^{2}$ We will begin with a brief survey of the practices known from the Achaemenid and Seleukid periods, followed by a discussion of the evidence from Arsakid Dura-Europos, a Seleukid foundation on the western bank of the Middle Euphrates, and the financial organization of the Babylonian temples under the Arsakids.

\section{I.1 From Achaemenid to Arsakid Officials}

The Persepolis Fortification Texts (PFT), dated to 509-457 BCE, provide important insights into Achaemenid administration, including the role of the high officials responsible for collecting community surplus, handling storehouses, and managing work groups. ${ }^{3}$ In the Achaemenid period, the satraps of a region oversaw the financial administration. In the PFT, we meet Parnaka, son of Aršāma, the chief administrator of Persepolis and close relative of the king. Parnaka had a travel authorization and was influential in handling the storehouses where in-kind taxes were collected. He was also entitled to grant travel authorization to his deputies and the managing satraps. Several higher officials were just below him, each in charge of one productive area from which revenue was collected. Parnaka communicated with them regularly about the delivery of specific products. Other officials oversaw the laborers

1 Lukonin 1983, 681-683.

2 Continuity and change in the Arsakid period are a complex matter, but the Arsakids do not seem to have introduced radical changes to the administration of the regions. See, e.g., Aperghis 2004, 289; van der Spek 2014; Monerie 2018, for Babylonia.

3 Briant (1996) 2002, 425-429 for the following.

Note: I would like to thank R. J. van der Spek, Lara Fabian and Sitta von Reden for comments and suggestions on earlier drafts of this chapter.

○ Open Access. (c) 2022 Razieh Taasob, published by De Gruyter. (cc) BY-NC-ND This work is licensed under the Creative Commons Attribution-NonCommercial-NoDerivatives 4.0 License.

https://doi.org/10.1515/9783110607642-006 
in the fields, shops, and construction sites. It seems plausible that Parnaka was in charge of the entire financial administration of the Achaemenid Empire. ${ }^{4}$

Alexander, though benefiting from the existing administrative system, seems to have effected some changes to the Achaemenid administrative apparatus. ${ }^{5}$ In most satrapies, including Egypt, he appointed several executives who were under his control and (in principle) had to report directly to him. He introduced or adapted a tripartite system of local government that included financial administrators (oikonomoi), a garrison commander (phrourachos) and a civil governor (satrap), who also had some military functions. He granted greater fiscal autonomy to the Greek cities of Asia Minor but maintained his right to collect tribute from the royal land outside their territory. ${ }^{6}$ The Seleukids adopted this system and made themselves authorities over the finances in their part of Alexander's empire. Nevertheless, the Asian satrapies (now also called eparchies or strategies) were not part of an integrated financial and administrative system but instead formed a loose network. ${ }^{7}$ Now two officials seem to have headed each satrapy, a satrap and a strategos. Both officials combined military and civil tasks, which, together with there being two officials in the same position, might be explained by the fact that in the Hellenistic Empires long-established Achaemenid and new Hellenistic officials acted alongside each other. ${ }^{8}$ Possibly, their coexistence also reflects different regional practices according to different degrees of royal administrative interference. ${ }^{9}$ Tax inspection and tax collection remained at the level of the satrapy, likewise operated by two kinds of local financial officials, oikonomoi and dioiketai. So-called epistatai ('overseers') were usually local elites appointed by the king who, along with the office of (urban) strategos, presided over poleis. A separate group of officials presided over temple revenue: a prostates in individual temples and an archiereus in larger regions. ${ }^{10}$ There is evidence, furthermore, that additional financial officers and military accounts offices (logisteria) controlled expenditure locally. ${ }^{11}$ At the top of the administrative structure was the epi ton prosodon ('the person in charge of the revenues'), who oversaw the imperial finances of the Seleukids as a whole. Local financial officers seem to have been subordinate to him and not to their local satraps. ${ }^{12}$

4 Aperghis 2004, 263-266.

5 Aperghis 2004, 266. There is some evidence that the eastern satrapies retained a greater degree of autonomy, but the motivation behind this differentiated administrative strategy is controversial; Aperghis 2004 for discussion.

6 Aperghis 2004, 87-88; Mileta 2008, 93; Monson 2015, 189.

7 Capdetray 2007, 227-239.

8 Von Reden, vol. 1, ch. 1, 33-35.

9 Capdetray 2007, 284-293 for discussion of this aspect.

10 Capdetray 2007, 321-329; Lukonin 1983, 714; temple prostates in Jerusalem: 2 Maccabees 3. 4.

11 Aperghis 2004, 289, with Landau 1961.

12 Aperghis 2004, 273; Capdetrey 2007, 321; see also von Reden, vol. 1, 32-35 for these and other offices in the Hellenistic Empires generally. 
Under the Arsakids, the multipolarity of the political system increased, which also contributed to greater administrative decentralization. ${ }^{13}$ Self-governing cities and sub-kingdoms with myriad variations ruled across the empire. ${ }^{14}$ The satrapy became a much smaller administrative unit, probably similar in size to the former Seleukid eparchy. ${ }^{15}$ In Dura-Europos, a strategos (combined with the office of epistates) continues to dominate the evidence of the public life of the city and appears to have been responsible for supervising the tax collection and finances of the larger administrative unit of Mesopotamia. ${ }^{16} \mathrm{He}$ might have been a royal appointee chosen from the local elite based in Dura-Europos. In the Nisa ostraca, hštrp ('satrap'), mrzwpn ('regional administrator') and dyzpty ('commander of a fortress') are mentioned alongside gzbry ('treasurer'), dprypty ('scribe'), and 'hmrkr ('accountant'). ${ }^{17}$ The editors of the documents have suggested that the marzbān was in charge of several satrapies, with Mithradatkert (Nisa) being the administrative center. ${ }^{18}$ Despite the differentiated set of local personnel involved in the fiscal administration, there is no evidence of any overarching tax collection office in any of the Arsakid royal centers, so taxes and other dues appear to have been collected from cities, temples, and regions under their own local or regional authority. The most striking indication of this fact is that the function of the epi ton prosodon is attested to have become part of the office of the strategos, thus collapsing central and local authority, as well as financial and other administrative tasks that had been distinct under the Seleukids. ${ }^{19}$

\section{Economic Actors in the Urban Administration: The Case of Phraates in Dura-Europos}

The cities in Arsakid Mesopotamia were basically self-governing, but their official and private dealings were guaranteed and authenticated by the Arsakid royal system. Taxes were collected by municipal officials, while empire-wide structures included private tax farming companies, titles of authority, and the treasury into which (at least some) taxes were paid. A portion of local taxes, along with penalty payments for breach of contracts, were paid to the treasury of the King of Kings. ${ }^{20}$

13 Lukonin 1983, 701.

14 Shayegan 2011, 291-296, 77-120; Weber 2010a, 100-104.

15 Lukonin 1983, 724.

16 Baird 2018, 65 and below, with P. Dura 20.

17 Weber in Hackl, Jacobs, and Weber 2010, 2:502-520 for a selection of texts and translations; see also the ostraca from Shahr-i Oumis, for which Bivar 1981

18 Lukonin 1983, 725-726; Jacobs in Hackl, Jacobs, and Weber 2010, 1: 94-96.

19 Capdetray 2007, 321.

20 Thus again Capdetray 2007, 321. 
However, we do not know the relative proportions of taxes filling the central and local treasuries nor whether taxes that remained in the region were assigned entirely to local purposes or also to royal affairs like provisioning armies and garrisons. ${ }^{21}$

Thanks to the excavation of a large body of papyri and parchments, the city of Dura- Europos provides particular insights into the practice of urban administration and its social underpinning under Arsakid rule. ${ }^{22}$ Dura (formerly Nikanoris) was a Seleukid foundation on the Middle Euphrates on the important junction between southern and northern Mesopotamia. ${ }^{23}$ It was taken by the Arsakids in ca. 116 BCE and remained under Arsakid control until 165 CE when it was conquered by the Romans. Under Arsakid domination, but in particular during the first and second centuries CE, Dura-Europos developed into a prosperous city that seems to have profited both from its location within the region and from being on the border between the Arsakid and Roman spheres of influence. ${ }^{24}$ Throughout the centuries, the city's institutions remained Hellenistic in nature, despite the fact that the city's population was of very mixed origin and descent. ${ }^{25}$ Like many other cities in the former Seleukid Empire, Dura-Europos was organized as a Greek-style polis with an exclusive citizen body of Europaioi. The public language was Greek, and dating formulae and calendar remained Seleukid, although from the Arsakid era onward, Arsakid year counts were added. ${ }^{26}$ Moreover, the main tax officials bore Greek titles and Seleukid status designations. Yet the latter now related to the Arsakid court. In the contracts P. Dura 18 (87 CE) and 19 (88/89 CE), we encounter a tax collector (praktor) and two royal judges (basilikoi dikastai) bearing the court titles of 'bodyguard' and 'first and most honored friend' associated with the Arsakid court. ${ }^{27}$

P. Dura 20 (121 CE) records a contract written in the Greek form of a double document and kept in the public record office in the city of Dura-Europos. The contract is an agreement of Phraates, eunuch and agent/subordinate of (ho para tou) Manesos. Though belonging to the retinue of Manesos, Phraates was still of high rank, as the title eunuch indicates. ${ }^{28}$ Manesos in turn is described as "paraleptos

21 Briant (1996) 2002, 408, with Herodotos 3. 90 (on Kilikia), according to whom about one third of the 500 talents of tax income was kept locally to provision the local cavalry, and two thirds were shipped to the king's treasury.

22 Cotton; Cockle and Millar 1995; Gregoratti 2016, 16; Baird 2018, 63-84, for further literature.

23 Gregoratti 2016, 19 for its nomenclature. Europos was its Greek name, while Dūr was the Semitic name of the original site of the city.

24 Compare with Palmyra which profited from a similar location, but played an even greater role in trans-local exchange; see von Reden, ch. 2, this volume.

25 Gregoratti 2016, 20-21 for the mixed population and the role of Greek in the town.

26 Baird 2018, 64-69; von Reden, vol. 1, ch. 1, 17-18; Wiesehöfer vol. 1, ch. 11, 480-482.

27 Von Reden, vol. 1, 29 for court titles in the Seleukid and Ptolemaic period. These titles, however, became institutionalized by the second century BCE, and may have been attached as a matter of formality to particular local positions; for their wider Durene context Baird 2018, 65; Lukonin 1983, 701-703 for possible equivalents in the Arsakid/Sasanian court titulature.

28 Lukonin 1983, 713. 
and strategos of Mesopotamia and Parapotamia and arabarchos."29 Judging from the tax administration of Roman Egypt, a paraleptos was a high tax official or the head of a tax farming company. ${ }^{30}$ Yet unlike in Egypt where a paraleptos was appointed by the arabarchos, who was his superior, Manesos combined both functions. Parapotamia was an administrative unit in northern Mesopotamia along the western bank of the Euphrates throughout the Seleukid, Arsakid, and Roman periods. ${ }^{31}$ It was governed from Europos, as the Dura papyrus suggests. Strabo describes it as a land of Arab chieftains and a part of Mesopotamia that was unsettled. ${ }^{32}$ The distinction between strategos and arabarchos thus pointed to the conceptual distinction of the administration of settled and unsettled people both being subject to Arsakid taxation in some way. Phraates, moreover, is titled arkapetēs ('chief collector of taxes'), a transliterated Iranian term for the office of argapet (hrkpty), which is also attested in Palmyra. ${ }^{33}$ We may assume that he was the head of tax collection at the level of the city or district that Manesos oversaw as strategos for the region of Mesopotamia and Parapotamia as a whole.

Most interesting to note, however, is the combination of private economic interests and administrative authority that an actor like Phraates was able to combine. ${ }^{34}$ Certain families seem to have inherited administrative offices, indicated by lines of descent conspicuously displayed in public inscriptions and contracts. ${ }^{35}$ Some status asymmetries were built into the system. Phraates, the eunuch, is designated by his being an agent or man of Manesos, while Manesos is called by his patronym.

P. Dura 20 contains an antichretic loan agreement, a well-known type of contract in which personal service, the usufruct of goods or land were offered in lieu of the interest of the loan. The contract was written down in the village of Peliga belonging to the district of Iardas and, like the previous contracts, kept in the record office of Europos. In the contract, Phraates agrees to allow a certain Baarlas to pay the interest on his loan through his servile labor (chreia doulika). If he missed a day's work, he would pay a penalty of one drachm to Phraates. If the loan was not repaid or not renewed at the record office of Europos after the initial year, Baarlas had to pay a penalty of 400 drachms to Phraates and the same amount into the royal treasury (basilikon). ${ }^{36}$ This was a merciless arrangement, and was likely never

29 P. Dura 201.5

30 De Romanis 2020, 7, and passim.

31 Cameron 2019, 135-137, 212-213 for this and the following.

32 Strabo 16. 2. 11.

33 Thommen in Hackl, Jacobs, and Weber 2010, 2: 450, 452 as well as Wiesehöfer, vol. 1, ch. 11, 485 with further references; see also Welles, Fink, and Gilliam 1959; Lukonin 1983, 745.

34 See von Reden, ch. 2, this volume, for their role in imperial economies.

35 Baird 2018, 66, 121-123 for elite family dynasties displaying their financial patronage of cults and religious buildings in public inscriptions; Gregoratti 2016, 25 argues that by the middle of the first century CE, the two offices of strategos and epistates were in the hands of just one family.

36 Lukonin 1983, 722 suggests that such penalty charges paid into the basilikon were an Arsakid innovation. 
meant to be affordable for a servile worker like Baarlas. There are other asymmetrical monetary loan agreements attested in the corpus of Dura parchments that effectively reduce the recipients to debt bondage to the social elite and administration. ${ }^{37}$ Phraates's social and administrative power, which he owed partly to his status as an agent of a person high up in the tax administration and partly to his own position in this administration, allowed him to contract an agreement that seems to have been based on practices of labor control developed in the social system of Hellenistic Dura.

Economic actors in the Arsakid Empire relied on imperial administrative and legal infrastructures that were recognizable and meaningful in local contexts. At the same time, the normative and social framework within which economic actors operated was local. The loan agreement that has survived from Dura-Europos required legal procedures that are unlikely to have prevailed outside urban environments in the Arsakid Empire. Imperial institutions allowed actors to fulfil both their local administrative tasks properly and to give legitimacy and validity to their own private economic affairs.

\section{Economic Actors in the Babylonian Temple Economy}

Another significant body of evidence for Arsakid financial actors comes from temples in Babylonia. A large body of cuneiform texts dating from the sixth to the first centuries BCE documents the nature of temple revenue management well. ${ }^{38}$ Babylonia formed the largest part of the very fertile region of central and southern Mesopotamia and had become an administrative unit under the Seleukids. Temples, together with royal domains, palaces, and large landowners, had driven the economy of the region since the Bronze Age. ${ }^{39}$ The city of Babylon itself, once the center of the large empire of Hammurabi, had been under changing imperial influences in subsequent centuries. ${ }^{40}$ It was reduced to a religious center by the Seleukids, who made Seleukeia-Tigris the nearby political center. Recurring periods of heavy warfare, combined with local unrest and rebellion, harmed the economy of the region in the Arsakid period, which is reflected in the volatility of prices for agricultural products that have survived in the records of the Astronomical Diaries. ${ }^{41}$ Notwith-

37 Baird 2018, 68-69, with P. Dura 17C; also van der Spek 2014, 208-209.

38 Wiesehöfer vol. 1, 485-486; Monerie 2018, 7-9 for a list of extant dossiers and archives.

39 Van der Spek 2007, 412.

40 Van der Spek 1998, 205.

41 Lukonin 1983, 719-721 for local unrest and civil strife in Seleukeia and other Mesopotamian cities; van der Spek 2007, 419 for the volatility of prices as affected by unrest; Huijs, Pirngruber, 
standing the conflicts in the region and the neighborhood of Seleukeia, the economic organization of the Babylonian temples seems to have remained intact well into the Arsakid period. Yet the vitality of the temples weakened when their representative role as preserves of Mesopotamian tradition in Babylon declined until they disappear from the records in the first century CE. ${ }^{42}$

The policy of both the Seleukid and Arsakid courts toward the temples was guided by munificence and generosity, not least since the kings relied on the economic and political cooperation of the temple elites. The kings presented themselves as servants of the gods, building and restoring temples and presenting offerings. ${ }^{43}$ High officials performed offerings to the temples when they visited the city, and the king intervened in the appointment of high temple officials. ${ }^{44}$ At the same time, they were able to draw income from temple property, sometimes in extortionate quantities or illegitimately. ${ }^{45}$ Although specific cases are known from the Seleukid period only, it is not inconceivable that such practices continued under the Arsakids.

The extant documents reveal the financial system, money, and property management of institutions below the level of the imperial court. To judge from the cuneiform tablets, temples in Babylonia acted largely separately from the royal administrative system. The temples generated and collected income that was spent within the temple organization, and maintained an organizational infrastructure for supervising and controlling the expenses. ${ }^{46}$ Unlike the example of urban administration, where royal agents and entrepreneurs bearing Greek names oversaw taxes and other public income, this does not seem to have been the case in Babylonia. The Rahim-Esu archive, relating to two years under Mithradates II (121-91 ВCE), and other Babylonian documents provide us with lists of officials, all bearing non-Greek titles and names, along with their functions and duties. ${ }^{47}$ Nevertheless, Greekspeaking administrative influence is visible in some rare Greek loan words in the Arsakid temple records, for example, purusutattesu for Greek prostates ('overseer'), or pulite for Greek politai ('citizens'). ${ }^{48}$

Temple revenue was derived from the exploitation of land and herds, as well as from taxes, donations, and service charges. ${ }^{49}$ Expenditure fell into three categories:

and van Leeuwen (2015, 142-143) develop a different scenario in which climatic change coupled with local rebellion and unrest caused production to decrease and prices to rise.

42 Monerie 2018, 440.

43 Van der Spek 2007, 412.

44 Van der Spek 2014, 215.

45 Van der Spek 2007, 412.

46 Monerie 2018, 308.

47 Van der Spek 1998 for a full list of texts and translations of the Rahìm-Esu archive.

48 McEwan 1981, 131; van der Spek 1998, 206.

49 Monerie 2018, 307. 
materials for sacrifices, repair of temples, and wages paid to laborers. ${ }^{50}$ Although the regular revenue and expenditure of the temples are well recorded, there is no single account reflecting their overall financial situation. It is well established, however, that the economy of Babylonian temples was more or less fully monetized, and the use of coinage, reckoned in terms of shekels nominally equivalent to half a Greek stater (two drachms), had become regular from the beginning of the Seleukid period..$^{51}$ None of the payments made in the temple records of the Arsakid period are made in kind, although the payment of rations, rents, and tithes in kind continued within Babylonia. Gold is a new arrival in the Arsakid temple records. It appears in small quantities as a gift given to either a king or a god. ${ }^{52}$

The fiscal system of the Babylonian temples does not seem to have changed significantly under Seleukid and Arsakid domination, and these periods are usually treated together by modern scholars. ${ }^{53}$ Land management and land leases remained widespread in Babylonia throughout both periods. ${ }^{54}$ Thus, the sūtu, a fee or tax imposed on tenants of temple lands, was one of the most significant sources of temple income under the Seleukids and likely remained so under the Arsakids. Private entrepreneurs were responsible for collecting and managing its collection. ${ }^{55}$ This can be seen in one of the Babylonian documents, CT 49 115, in which the name of an entrepreneur Muranu is mentioned as an official who managed the Esagila land..$^{56}$

Finances were supervised by a board of officials known as šatammus who acted together with the members of the kiništu ('assembly') of the temple of Esagila. The šatammu was something like a 'chief temple administrator, ${ }^{57}$ who, together with the kiništu, was charge of the entire temple organization of Babylonia throughout the Seleukid and Arsakid periods. ${ }^{58}$ The šatammus and kiništu also decided about religious matters and were the addressees of royal orders concerning the city of Babylon.

Private entrepreneurs were in charge of collecting, storing, and managing taxes and other income of the temples. ${ }^{59}$ Since the sixth century BCE, Babylonian records

50 McEwan 1981, 131.

51 Jursa 2006; Monerie 2018; van der Spek 2014, 205-206, also for a brief survey of the increasing debasement of Seleukid and Arsakid coins, which made the equivalence nominal. Cf. also van der Spek 2017.

52 McEwan 1981, 132, 137, with $A B 245$ = van der Spek 1998, 239, no. 26.

53 McEwan 1981; van der Spek 2000; Monerie 2018.

54 Monerie 2018, 309.

55 Jursa 2006, 146 n. 27, 161-162. Stolper believes that there was a mechanism of standing order guiding the temple staff in how to manage temple assets in which the crown had an interest, Stolper 1993, 61; van der Spek 2014, 208.

56 Joannès 1982, 126-172.

57 Van der Spek 1984, 545.

58 Van der Spek 2000, 438, also for the following.

59 Van der Spek 2014, 208 with Jursa 2006, 146 n. 27, 161-162. 
show the practice of leasing rights to income against the payment of a fixed sum, a custom well known from other fiscal and agrarian contexts in antiquity, including Hellenistic Egypt. ${ }^{60}$ Michael Jursa was able to demonstrate that these revenues were collected within wider portfolios of economic activity. Entrepreneurial individuals, such as the family members of the Murānu active in Babylonia (early Hellenistic period), managed monetary and agrarian assets of both temples and estate holders. ${ }^{61}$ The practice continued in the times of the Rahīm-Esu records. Rahìm-Esu himself may have been an entrepreneur or high-ranking administrator in Babylonia, with whom the income from several Babylonian temples was deposited. There were other officials who held other titles such as 'watchman of the counsel house' as well as another named official, Marduk-šuma-iddin. ${ }^{62}$ The latter was in charge for the cashboxes of Esabad, whereas Rahīm-Esu had acquired the right to control the 'basket' (hallatu) of the Esagila temple, where the income from the cashboxes of other Babylonian temples was also deposited. It has long been assumed, however, that Rahìm-Esu controlled the basket by virtue of being a high official in the administrative hierarchy. ${ }^{63}$ His status is not clearly documented in the archive, but he was not a šatammu.

CT 49, no. 160 is a contract in which the rights to collect and manage the income of the cashbox from the Day-One/All-Day temple in Babylon are leased to a priest called Bēl-aba-uṣur, son of Bēll-iddina. ${ }^{64}$ The lessor, Bēl-tabtani-bullit, acted as the representative of the šatammu Bēl-bullissu in this and in another document. The šatammu apparently acted through local representatives who contracted out the rights to collect the revenue of particular temples. The fact that the lessee was a priest himself is probably irrelevant, as professionals of all kinds are attested as lessees of the rights to temple assets.

The business of financial entrepreneurs like Bel-aba-uṣur and Rahīm-Esu overlapped with that of people who managed money and in-kind property deposited in temples by other individuals. Most of these depositors were involved in the administration of revenues, either as rent farmers or tax collectors, ${ }^{65}$ another practice that spanned many periods. A number of depository notes from the Hellenistic period are extant and have been carefully studied by Stolper and Jursa. ${ }^{66}$ Most notes describe the deposit, name of the depositor, the depositary, and the stipulation that the deposit is to be paid back on demand. Others go further, establishing that the

\footnotetext{
60 Bingen 1978.

61 Jursa 2006; van der Spek 2014; see also von Reden, ch. 2, this volume.

62 Van der Spek 1984, 547.

63 Van der Spek 1998, 246 discusses both possibilities, while van der Spek 2014, 208 and Jursa 2006, 171-172 opt for the former.

64 Van der Spek 1998, 237 no. 24 (93 BCE) with commentary ad loc; for the É DU.1.KAM (Day-One/ All-Day-temple), see most recently Hackl 2020.

65 Jursa 2006, 172.

66 Stolper 1993; taken further by Jursa 2006, 162-180; van der Spek 2014, 205-209.
} 
deposit may be paid to anyone who produces the depository document, and that it must be paid out wherever the depositor wishes. This made depository notes equivalent to promissory notes deployable as negotiable monetary instruments. ${ }^{67}$ In yet other notes, the deposit is said to be turned into a loan bearing interest once it is not returned on demand or at the stipulated place. The interest payable to the creditor (depositor) was double the amount of the normal 20 percent of the principal per year. This makes it unlikely that the conversion of the deposit into a loan was in the interest of the deposit holder, or that such deposits were in fact intended to be loans to him. Yet as depository notes were used as negotiable instruments equivalent to a check, and the conversion into an interest-bearing loan appears to have been fixed in writing shortly before the repayment was due, Jursa concludes that deposits were used as capital by the depositary for some time, and only upon recall incurred the obligation to pay interest/penalty in case of nonrepayment on time. This made deposit holders de facto bankers, and in their capacity for using the deposits of others as capital, they were distinct from professionals like Rahìm-Esu who were responsible for the income and expenditure of temple revenue alone.

The financial operations of administrators and entrepreneurs within the temple economy benefited from the legal and institutional framework of the imperial administration. The extant evidence belongs to the Seleukid period, but the relative scarcity of records from the Arsakid period, coupled with one extant record that mentions a royal edict (dātā; dātu) likely promulgated in the Achaemenid period, suggests that the regulatory framework was not affected substantially by the changing imperial systems. ${ }^{68}$ For example, a record of deposit from the Mūrānu archive contains the clause, "anyone who holds the [depository] document may collect that twelve shekels of silver, that is, that deposit, according to the royal decree." 69 Another contract from the early third century BCE stipulates that if a debtor (of barley) does not pay it back at the appointed time, he will pay double; and if he does not

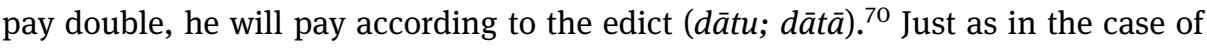
the evidence from Dura-Europos, though relating to a very different sociopolitical context, an administrative system of collecting and managing taxes operated locally, but within an imperial institutional frame from which it benefited. Moreover, financial entrepreneurs, closely attached to temples, increased their economic opportunities and power from their status in the tax administration. In combination with the institutional frame of the empire, which provided greater security to their transactions and introduced a dynamic entrepreneurial factor into the local econo-

67 Jursa 2006, 159.

68 Cuneiform Texts from Babylonian Tablets in the British Museum (CT) 49, no. 102 (= Stolper 1993, 51-53) with van der Spek 2014, 207, see also below.

69 Van der Spek 2014, with CT 49, no. 173: 9-11 (= Stolper 1993, 25-27 no. 8); Jursa 2006, 200.

70 Van der Spek 2014, with CT 49, no. 102 (= Stolper 1993, 51-53). 
my of Babylon, they may have contributed to the expansion of long-distance trade that connected Mesopotamia to the Indian Ocean and Mediterranean world. ${ }^{71}$

\section{References}

Aperghis, G. G. 2004. The Seleukid royal economy: The finances and financial administration of the Seleukid empire. Cambridge: Cambridge University Press.

Baird, J. 2018. Dura-Europos. London: Bloomsbury Academic.

Bingen, J. 1978. "The third-century land-leases from Tholthis." Illinois Classical Studies 3, 74-80.

Bivar, A. D. H. 1981. "The second Parthian ostracon from Qūmis (Qūmis commentaries no. 3)." Iran 19.1, 81-84.

Briant, P. (1996) 2002. From Cyrus to Alexander: A history of the Persian empire. Winona Lake, IN: Eisenbrauns. Originally published as Histoire de l'Empire perse: De Cyrus à Alexandre.

Cameron, H. 2019. Making Mesopotamia: Geography and empire in a Roman-Iranian borderland. Leiden: Brill.

Capdetrey, L. 2007. Le pouvoir séleucide: Territoire, administration, finances d'un royaume hellénistique, 312-129 avant J.-C. Rennes: Presses universitaires de Rennes.

Cotton, H. M., W. E. H Cockle, and F. G. B. Millar. 1995. "The papyrology of the Roman Near East: A survey." Journal of Roman Studies 85, 214-235.

De Romanis, F. 2020. The Indo-Roman trade and the Muziris Papyrus. Oxford: Oxford University Press.

Gregoratti, L. 2016. "Dura-Europos: A Greek town of the Parthian empire.” In T. Kaizer (ed.), Religion, society and culture at Dura-Europos, 16-28. Cambridge: Cambridge University Press.

Hackl, J. 2020, "Nochmals zum é ud.1.kam und seiner vermeintlichen Rolle im babylonischen Neujahrsfest - ein Beitrag zur Kulttopographie Babylons in hellenistischer Zeit", Zeitschrift für Assyriologie, online edition. https://doi.org/10.1515/za-2020-0019.

Hackl, U., B. Jacobs, and D. Weber, eds. 2010. Quellen zur Geschichte des Partherreiches. 3 vols. Göttingen: Vandenhoek \& Rupprecht.

Huijs, J., R. Pirngruber, and B. van Leeuwen. 2015. "Climate, war and economic development: The case of second-century BC Babylon.” In R. J. van der Spek, B. van Leeuwen, and J. L. van Zanden (eds.), A history of market performance: From ancient Babylonia to the modern world, 128-148. Routledge: London.

Joannès, F. 1982. Textes economiques de la Babylonie récente. Paris: Editions Recherche sur les civilisations.

Jursa, M. 2006. "Agricultural management, tax farming and banking: Aspects of entrepreneurial activity in Babylonia in the Late Achaemenid and Hellenistic periods." In P. Briant and F. Joannès (eds.), La transition entre l'empire achéménide et les royaumes hellénistiques (vers 350-300 av. J.-C.), 137-222. Paris: De Boccard.

Landau, Y. H. 1961. "A Greek inscription from Acre." Israel Exploration Journal 11, 118-126.

Lukonin, V. G. 1983. "Political, social and administrative institutions: Taxes and trades." In E. Yarshater (ed.), The Cambridge history of Iran. Vol. 3.2, 681-746. Cambridge: Cambridge University Press.

McEwan, G. J. P. 1981. “Arsacid temple records.” Iraq 43.2, 131-143.

71 Monerie 2018, 426-435. 
Mileta, C. 2008. Der König und sein Land: Untersuchungen zur Herrschaft der hellenistischen Monarchen über das königliche Gebiet Kleinasiens und seine Bevölkerung. Berlin: Akademie Verlag.

Millar, F. 1998. "Dura-Europos under Parthian rule.” In J. Wiesehöfer (ed.), Das Partherreich und seine Zeugnisse / The Arsacid Empire: Sources and documentation, 473-492. Stuttgart: Franz Steiner.

Monerie, J. 2018. L'économie de la Babylonie à l'époque hellénistique. Berlin: De Gruyter.

Monson, A. 2015. "Hellenistic Empires." In A. Monson and W. Scheidel (eds.), Fiscal regimes and the political economy of premodern states, 169-207. Cambridge: Cambridge University Press.

Shayegan, M. R. 2011. Arsacids and Sasanians: Political ideology in post-Hellenistic and Late Antique Persia. Cambridge: Cambridge University Press.

Stolper, M. W. 1993. Late Achaemenid, early Macedonian and early Seleucid records of deposit and related texts. Annali dell'Istituto Orientale di Napoli, Suppl. 77. Naples: Istituto Universitario.

van der Spek, R. J. 1985. "The Babylonian temple during the Macedonian and Parthian domination." Bibliotheca Orientalis 42, 541-562

-. 1998. "Cuneiform documents on Parthian history: The Rahimesu archive materials for the study of the standard of living." In J. Wiesehöfer (ed.), Das Partherreich und seine Zeugnisse / The Arsacid Empire: Sources and documentation, 205-258. Stuttgart: Franz Steiner.

-. 2000. "The šatammus of Esagila in the Seleucid and Arsacid periods." In J. Marzahn, H. Neumann, and A. Fuchs (eds.), Assyriologica et Semitica: Festschrift für Joachim Oelsner anlässlich seines 65. Geburtstages am 18. Februar 1997, 437-446, Münster: Ugarit-Verlag.

-. 2007. "The Hellenistic Near East." In W. Scheidel, I. Morris, and R. Saller (eds.), The Cambridge economic history of the Greco-Roman world, 409-433, Cambridge: Cambridge University Press.

-. 2014. "Factor markets in Hellenistic and Parthian Babylonia (331 BCE-224 CE)." Journal of the Economic and Social History of the Orient 57.2, 203-230.

-. 2017. "Manûtu ša Bābili: The Babylonian subdivision of the mina." Nouvelles assyriologiques brèves et utilitaires no. 1, 33-37 (no. 20).

Welles, C. B., R. O. Fink, and J. F. Gilliam. 1959. The excavations at Dura-Europos. Final report. Vol. 5.1, The parchments and papyri. New Haven CT: Yale University Press. 